\title{
The Innovative Development of Party Building in Colleges and Universities in the Internet+ Era
}

\author{
Hao Wang* \\ Shenyang Conservatory of Music, Shenyang 100081, Liaoning, China. \\ E-mail: 1093624752@qq.com
}

Abstract: Entering the Internet era, with the popularization and deepening of Internet technology, "Internet+" has begun to be used in all walks of life. In this era, the party building work in colleges and universities has entered a new stage of development. The text begins with the analysis of the significance of "Internet +" to college party building work, focusing on the problems in college party building work and the innovative development of college party building work in the Internet + era. It is hoped that the advantages of the Internet will comprehensively improve the quality of party building work in colleges and universities in China.

Keywords: Internet; Party Building in Colleges and Universities; Problem Analysis; Work Innovation

The advent of the "Internet +" era has pushed China's universities into a new stage of development. Colleges and universities are important bases for party-building work. The practice has proved that the organic combination of "Internet technology" and "party building work" can effectively improve the quality of party building work in colleges and universities. Of course, the combination of "Internet technology" and "party building work" requires attention to methods. In order to give full play to the role and advantages of Internet technology, college faculty and staff must first clearly understand the significance of "Internet+" in college party-building work.

\section{The significance of "Internet + " to party building in colleges and universities}

\subsection{Improve the efficiency of party building work and enrich the content of party building work}

After Internet technology enters the campus, it not only has an important impact on college education and teaching, but also exerts a positive effect on college party building. Specifically, on the one hand, the emergence of the new model of "Internet + party building work" has brought much convenience to specific party-building work. Communication, discussion, and learning about party building work can all be achieved through the Internet. Breaking through the limitations of time and space, Internet technology greatly improves the efficiency of party building work, prompting faculty and staff to accomplish more things at the same time. On the other hand, after the emergence of the new model of "Internet + party building work", the content of party building work has become more diversified. Through multimedia and various social software, such as WeChat, QQ, etc., college faculty and staff can learn party-building knowledge with pictures, texts and animation videos, and can also use these information platforms to transfer party-building knowledge, which not only enriches the content of party building in colleges and universities, but also fully arouses the enthusiasm of party building participants. This shows that the emergence of the new model of "Internet+ party building work" has improved the efficiency of party building work and enriched the content of party-building work.

\subsection{Establish a party-building information supervision platform to improve the deficiencies of party building work}

Internet technology can realize information sharing and information interaction, and can create an informationized supervision platform. What role can such a supervision platform play in party building in colleges and universities? Copyright $\odot 2020$ Hao Wang

doi: $10.18282 /$ le.v9i6.1300

This is an open-access article distributed under the terms of the Creative Commons Attribution Non-Commercial License

(http://creativecommons.org/licenses/by-nc/4.0/), which permits unrestricted non-commercial use, distribution, and reproduction in any medium, provided the original work is properly cited. 
First, after the emergence of the new model of "Internet + party building work", colleges and universities can establish a "party building information supervision platform" to conduct reasonable supervision and control party building work from various aspects such as party building work, party-building learning, and party building propaganda. The quality of the party building has promoted continuous optimization and upgrading of party-building work. Second, after the emergence of the new model of "Internet + party building work", the "party-building information supervision platform" established by universities can exert positive effects in many aspects. In terms of operation mode, the party building information supervision platform can not only realize top-down supervision and management, but also open up supervision and feedback channels from bottom to top, such as e-mail, WeChat community, etc. Party-building workers can use these channels to gather various suggestions, improve the deficiencies in party building work, and improve the quality of party building work in colleges and universities. In this process, the party building work has brought into play the strength of the masses and strengthened the contact between the party and the masses. This is an important connotation of party-building work.

\section{Problems Existing in Party Building Work in Colleges and Universities}

\subsection{The quality of party building workers in some universities is not high}

In college party building work, the quality of party building workers is uneven, which seriously affects the overall quality of party-building work. The low quality of party building workers in some colleges and universities is mainly manifested in the following aspects. On the one hand, society is developing, science and technology are progressing, and the connotation of party building work in colleges and universities should be continuously enriched. However, in reality, some college party-building workers hold traditional and conservative concepts and are unwilling to learn new knowledge or accept new ideas. If the party building workers themselves are not high-quality and have limited knowledge reserves, it will be difficult to enrich the connotation of party building work in the new era. Under such circumstances, the party building work of colleges and universities will gradually deviate from actual needs, lack of practical significance, and cannot give full play to the role and advantages of party-building work. On the other hand, in the process of carrying out party building work in colleges and universities, some party-building workers are used to play the role of the "listener" are unwilling to be "innovators" and "pioneers". Entering the Internet age, there are many ways for party building. If one is not good at innovation and dare to explore, it will be difficult to adapt to the needs of party building in the new era.

\subsection{Some colleges and universities' party-building work model is relatively backward}

The mode of party building work in some colleges and universities is relatively backward. The specific manifestations are as follows: First, in the process of carrying out party building work in colleges and universities, some party-building workers are not good at opening channels for online communication, online learning, and online activities through information technology, resulting in a traditional and mechanical way of party building work, which has not changed year after year. Without the support of information technology, party-building work in colleges and universities can often only be carried out through meetings, lectures, etc., and has strict requirements on time and space. Moreover, the traditional party building work model is too single, which is not conducive to mobilizing the enthusiasm of party building workers in the new era. Second, in the process of carrying out party building work in colleges and universities, the traditional party building work model emphasizes "top-down" inculcation of theoretical knowledge. For party-building participants, indoctrination learning does not fully mobilize the enthusiasm of learners and cannot carry out benign interactions, which is not conducive to the development of party building in colleges and universities in the direction of openness, sharing, and people-friendly.

\section{The innovative development of party building in colleges and universities in the Internet+ era}

\subsection{Create an "online classroom for party building in colleges and universities" to improve the quality of party-building workers in colleges and universities}

In the context of the Internet+ era, in order to effectively improve the quality of college party-building workers, on the one hand, with the development of society and the advancement of science and technology, colleges and universities must continuously enrich the connotation of party-building work. Colleges and universities should encourage party-building workers to actively change their concepts and organize regular training and learning for party-building 
workers. With the advantages of Internet technology, colleges and universities can open online learning channels and create online classrooms for party building in colleges and universities. For example MOOC, Douyin live class, Chaoxing platform, etc., these platforms can break through the limitations of time and space to teach online. Through these learning methods, the enthusiasm of party building workers can be better mobilized. On the other hand, in the process of carrying out party building work in colleges and universities, colleges and universities should encourage party-building workers to dare to be "innovators" and "pioneers." In the Internet age, colleges and universities should adopt a more tolerant attitude and allow party-building workers to open up online and offline party-building channels. For example, after an offline party-building activity of "singing the red song" is organized, party-building workers can publish relevant reports on "singing the red song" on the WeChat public account of colleges and universities to expand the influence of party-building activities.

\subsection{Innovate online feedback channels and improve the work model of party building in colleges and universities}

In order to comprehensively improve the quality of party building work in colleges and universities, colleges and universities must actively improve the deficiencies in party-building work. Specifically, first, in the process of carrying out party building work in colleges and universities, party-building workers must be good at using information technology to open channels for online communication, online learning, and online activities to maintain the advanced nature of party-building work. For example, on the 99th anniversary of the founding of the Communist Party of China, colleges and universities can make the 99th anniversary "commemorative edition of Yiqixiu", telling about the glorious history of the party's 99th anniversary and the party building work since the establishment of the college. "Yiqixiu" is a way of network propaganda, which is easy to spread on mobile phones, including pictures and music. It is an online browsing method that contemporary college students are willing to accept. Second, in the process of carrying out party building in colleges and universities, the party-building work cannot be just "to inculcate theoretical knowledge by teachers, and to provide feedback from the bottom up, can we continuously improve the deficiencies in the party building work. For example, party-building workers can initiate activities such as "email solicitation for papers", "WeChat community discussion" and other activities, focusing on topics like "what do you think about this party building work" and "please rate the best performers in this party-building activity". In this process, the openness of the Internet can promote the interaction of party building work, and promote the development of party building work in colleges and universities in the direction of openness, sharing, and people-friendly.

\section{Conclusion}

From computer terminals to mobile terminals, with the continuous development of Internet technology, the Internet will have an increasing influence on the party building work of colleges and universities. In the future, in addition to learning to use Internet technology to improve the efficiency of party building work, college faculty and staff must also learn to innovate the use of the Internet, invigorate the party building work atmosphere, and open up a unique party-building path in line with the university environment, so as to promote the party building work of colleges and universities to become more standardized and develop in a more systematic and advanced direction.

\section{References}

1. Xin R, Sun X, Zhao J. Analysis of party school construction in colleges and universities from the perspective of "Internet+. Reform and Opening 2018; (8): 117-118.

2. Liu H. Research on the party building work of College Students under the Background of "Internet+". Reform and Opening 2018; 495(18): 78-80.

3. Li Y. Research on the characteristics and innovation of the basic-level party building work in colleges and universities. Science and Technology Outlook 2017; (18): 347.

4. Li Y. Innovative research on college party building works in the context of Internet+. Social Science Research 2019; (9): 277-279.

5. Liu Y, Chu R. Innovative research on the party building work of college students led by the trend of "learning to strengthen the country". Changjiang Series 2019; (5): 157-159.

6. Zhang J. Innovation and practice of "Internet + Party Building" work in colleges and universities. Education Teaching Forum 2017; (10): 141-142. 